\title{
İlkokul Öğrencilerinin Sınıftaki Davranışlarına Kitle İletişim Araçlarının Etkisi
}

\section{The Effect of Means of Mass Communication on Primary School Students' Behaviour in the Classroom}

\section{Kenan BİRGÜL * Selma GÜLEÇ** Ömer Faruk TAVŞANLI ${ }^{* * *}$}

\begin{abstract}
$\ddot{O}_{z}:$ Bu çalışmada kitle iletişim araçlarının ilkokul öğrencilerinin sınıftaki davranışlarına etkisinin incelenmesi amaçlanmaktadır. Araştırmanın çalışma grubunu 2014-2015 öğretim yılında Bursa ili Yıldırım, Nilüfer ve Osmangazi ilçelerinde yer alan Milli Eğitim Bakanlığı'na bağlı ilkokullarda görev yapan 84'ü kadın ve 66'sı erkek olmak üzere 150 sınıf öğretmenleri oluşturmaktadır. Çalışmada, Çalışkan-Ülkü (2011) tarafında geliştirilen "Kitle İletişsim Araçlarının İlköğretim Öğrencilerinin Sinıf İçi Davranışlarına Etkisi Üzerine Öğretmen Görüşleri Ölçeği” kullanılmıştır. Ölçeğin güvenirliğini belirleyen Cronbach Alfa güvenirlik katsayısının 0.93 olarak bulunduğu ifade edilmiştir. Elde edilen verilerin istatistiksel analizinde SPSS 20.0 paket programı kullanılmıştır. Verilerin normallik dağılımını kontrol etmek için Kolmogorow-Smirnow testinden faydalanılmıştır. Veriler normal dağılım gösterdiği için parametrik testlerden olan Indepent Samples T testi ve Tek Yönlü Varyans Analizi (ANOVA) testleri kullanılmıştır. Araştırmada, sınıf öğretmenlerinin kitle iletişim araçlarının sınıf içi öğrenci davranışlarına etkisine ilişkin görüşlerinde cinsiyet, mesleki kıdem, görev yapılan yer, ikamet edilen yer ve ekonomik düzey bakımından anlamlı bir farklılık olmadığı sonucuna ulaşılmıştır.
\end{abstract}

Anahtar sözcükler: İletişim ve Teknoloji, Sınıf Öğretmeni, Öğrenci Davranış

\begin{abstract}
The purpose of this study was to determine the effect of means of mass communication on primary school students' behaviour in the classroom. The study group comprised classroom teachers working in primary schools connected to the Ministry of National Education located in the Yildirim, Nilufer and Osmangazi districts of Bursa in the 2014-2015 educational year. Of these teachers, 84 were female and 66 were male. In the study, the "Scale for Teacher Opinions on the Effect of Mass Communication Means on Primary School Students' Behaviours in the Classroom" developed by CaliskanUlku (2011) was employed. The Cronbach's alpha coefficient determining the reliability of the scale in this study was found to be 0.93 . In the statistical analysis of the obtained data the SPSS 20.0 package program was used. In order to check if the data was distributed normally, the Kolmogorov-Smirnov test was used. Since the data was distributed normally, the Independent Samples T test, a parametric test, and the One-Way ANOVA test were employed. In the study, it was found that the classroom teachers' opinions about the effect of means of mass communication on students' behaviour in the classroom did not differ significantly according to their gender, length of service, place of service, place of residence or their economic status.
\end{abstract}

Keywords: Communication and Technology, Classroom Teacher, Student Behaviour

\footnotetext{
* Sınıf Öğretmeni, Nurettin-Gülten Kutlucan İlkokulu, Bursa. kenanbirgul@gmail.com

** Yrd. Doç. Dr., Uludağ Üniversitesi, Eğitim Fakültesi, Sosyal Bilgiler Öğretmenliği ABD, Bursa. sgulec@uludag.edu.tr

${ }^{* * *}$ Arş. Gör., Uludağ Üniversitesi, Eğitim Fakültesi, Sınıf Öğretmenliği ABD, Bursa. omerfaruktavsanli@gmail.com
} 


\section{Giriş}

Batılıların "communication" diye ifade ettiği iletişim "anlamları bireyler arasında ortak kılma" şeklinde tanımlandığı gibi teknik bir dille "bir kaynağın, bir mesajı, bir kanal üzerinden bir alıcıya iletme süreci" ş̧eklinde de tanımlanmaktadır. İletişim terimi Latince "bölüşmek" anlamına gelen "communis" kelimesinden gelmektedir. Bu bağlamda iletişim bilgi, düşünce ve deneyimlerin bireyler veya gruplar arasında aktarılmasını sağlamak için gerçekleştirilen eylemler olarak tanımlanmaktadır. İletişimi sadece haberleşme anlamında değil, bireyler ve gruplar arasındaki her türlü ilişki bağlamında düşünmek gerekmektedir. Bu noktada iletişim, bireyler ve gruplar arası kavram ve sembol iletimi olarak da ifade edilmektedir (Nacar 2010).

Kavramlar ve semboller ile insanlar arasında ilişki kurmak anlamına gelen iletişim insanların birbiriyle konuşma ve anlaşma isteğiyle başlamaktadır. Başka bir deyişle iletişimin oluşabilmesi için kişiler ya da gruplar arasında karşılıklı iletilerin aktarılması sonucu etkileşimin ya da paylaşımın olması gerekmektedir. Bu nedenle de iletişim; duyguların, düşüncelerin, hislerin, görüşlerin, bilgilerin aktarımı ya da alışverişi olarak da görülmektedir (Gökçe 2006).

İnsanların, belirli bir grup ya da topluma uyum sağlama istekleri ve kendi çıkarlarıyla ilgili çeşitli beklentiler içerisinde olmaları, gerçek ve doğal ilişkiler yerine, kişiliklerine yapay roller yükleyerek yapmacık ilişkiler kurmasına neden olmaktadır. Bu süreç, çeşitli iletişim çatışmalarının nedenleri arasında sayılabileceği gibi, insanlar arası işbirliği, dayanışma duygularının etkisizleşmesine de neden olabilmektedir (Cüceloğlu 2002).

Bireyin iletişim tarzının gelişiminde, yakın çevredeki ve aile içindeki bireyler ile sürdürdüğü diyalog tarzı ve öğretmen-öğrenci etkileşimi hayati bir önem taşımaktadır. Özellikle okul çağındaki çocuklar için öğrenci-öğretmen arasındaki ilişkinin, öğrencilerin kişilik gelişimi ve doğru ilişki stratejileri geliştirmeleri üzerinde etkili olduğu bilinmektedir. Öğrenci-öğretmen arasındaki etkileşimin öğrenciler üzerinde olumlu olarak yapılandırılması için, öğretmenin derste ve ders dışında, öğrenciler ile etkili bir iletişim kurması gerekmektedir (Smith \& Laslett 1996; Çam 1997).

Öğretmenlerin öğrenci ile etkili iletişim kurabilmeleri öğrenme sürecini olumlu etkileyebileceği gibi öğrencilerin birey olarak gelişimlerini de olumlu etkilemektedir. Bu noktada öğretmenin sadece karşı tarafın duygularını ve mesajlarını alabilmesi değil, iletişim kurduğu bireylerin duygularını da anlayarak sürdürebilmesi gerekmektedir. Öğrencinin sürekli alıcı, öğretmenin ise sürekli verici rol oynadığı iletişim türü tek yönlü bir iletişim özelliği göstermektedir. Oysa öğrenci ve öğretmenin hem kaynak hem de alıcı rolünü oynadığı ve karşılıklı olarak çift yönlü iletişimin sağlanabildiği sınıflar iletişimin doğru olarak yapılandırıldığı sınıflar olarak gösterilmektedir. Öğrenci katılımı ile öğrencinin öğrenme sürecinde aktif olduğu bir öğrenme atmosferi oluşturma öğretmenin sorumluluklarından biri olarak karşımıza çıkmaktadır. Öğrencinin öğrenme sürecinde aktif olduğu bir öğrenme atmosferinin, öğretmenin sınıf ile olumlu iletişim kurduğunda meydana geldiği bilinmektedir (Çetinkanat 1997).

Öğretmenlerin yükseköğretim kurumlarında öğretmenliğin gerektirdiği bilgi ve becerilerle donanmış olarak mezun olmalarına rağmen atandıkları okullardaki iş arkadaşları, okulun kurumsal yapısı ve okul içi iletişimdeki farklılıklar sebebiyle iletişim becerilerinin değişim gösterdiği ifade edilmektedir. Öğretmenin mesleki sosyalizasyonu olarak nitelendirilebilen bu süreçte, öğretmen iş arkadaşları, yönetici ve veliler ile kurduğu iletişim biçimi aracıllğı ile yeni sosyal öğrenmeler gerçekleştirmekte ve bu öğrenmeler öğretmenin sınıf içi iletişimini de etkilemektedir (Pehlivan 2005).

Öğretmenin etkili iletişim becerilerine sahip olma düzeyinin, hem öğretmen-öğrenci arasın- 
daki ilişkinin hem de öğretimin niteliğinin arttırılmasında önemli bir role sahip olduğu bilinmektedir. Öğrenciler, öğretmenin zihnindeki bilgilere, düşüncelere, aklından geçirdiklerine değil; gerçekleştirdiği hareketlere, söylediği sözlere, beden diliyle ifade ettiklerine, sevincine, nefretine, öfkesine, güler yüzlülüğüne ve düşüncelerini ifade ediş biçimine bakarak pozisyon almaktadır. Bu sebeple öğrencilerin öğrenme isteklerini arttırmak, onları harekete geçirmek ve eğitim açısından motive etmek için öğretmenlerin sosyal iletişim ve etkileşim stratejilerine hâkim olmaları gerekmektedir (Şencan 2010).

Öğretmen ve öğrencilerin etkileşim içerisinde olduğu ve birbirlerinin davranışlarını en çok şekillendirdiği ortamın eğitim-öğretim faaliyetlerinin sürdürüldüğü sınıflar olduğu bilinmektedir (Halawah 2005). Aynı sınıf içerisinde farklı kültürlerden, farklı sosyo-ekonomik yapılardan, farklı din ve inançtan öğrenciler bulunabilmektedir. Bu farklılıklar, sınıf içerisinde bir bütünlük kazanarak sınıfın iklimini oluşturmakta ve oluşan bu iklim de yine en çok öğrenciler üzerinde etkili olmaktadır (Ayers \& Gray 1998; Little 2005; Çakmak, Kayabaşı \& Ercan 2008; Tavşanlı, Birgül \& Oksal 2015). Ülkemizde son yıllarda artış gösteren şiddet, fiziksel ya da psikolojik baskı ve çeteleşme gibi davranışların ilkokul seviyelerine inmesi, öğrenciler ile doğru iletişim stratejileri geliştirmenin önemini açık bir şekilde göstermektedir (Üre 2003).

Öğrencilerin davranışlarını etkileyen faktörler zaman içinde değişmekte ve çağın koşullarına göre farklılık göstermektedir. Yaşadığımız çağ olan bilgi ve teknoloji çağı, 21. yüzyıl insanını televizyon, radyo, bilgisayar, tablet, internet, akıllı telefon ve elektronik reklam panoları gibi birçok elektronik iletişim aracıyla karşı karşıya getirmektedir. Bu durum çocuğun toplumsallaşmasına etki eden unsurların içerisine kitle iletişim araçlarının da dâhil olmasını sağlamıştır (McQuail 2010). Kitle iletişim araçlarının en belirgin özelliğinin bilgiyi hızlı bir şekilde büyük kitlelere aktarma olduğu bilinmektedir (Hirsch \& Silverstone 2003). Bilginin kitle iletişim araçları aracılığı ile çok hızlı bir şekilde yayılması ve kitle iletişim araçlarının her eve girerek yaygınlık göstermesi, çocukların haber kaynaklarına yeni bir aracın eklenmesi gibi bir sonucu doğurduğu görülmektedir (Çalışkan-Ülkü \& Demir 2013).

$\mathrm{Bu}$ haber kaynaklarını daha çok internet siteleri, sosyal ağ siteleri (facebook, msn, twitter, instgram), televizyon, radyo, sinema ve çeşitli basılı yayınlar oluşturmaktadır (Kio \& Negreiros 2013). Bahsedilen kitle iletişim araçlarının içindeki en yeni ve en popüler olanı sosyal medyadır. Bilişi̇m teknolojilerindeki hızlı ilerlemeye bağlı olarak dünyada olduğu gibi ülkemizde de internet kullanımı her geçen gün artmakta ve bu durum da daha fazla sosyal medya kullanımını teşvik etmektedir.

Yapılan araştırmalara göre A.B.D'de çocuklar her gün ortalama üç saat, Türkiye'de ise hafta içi üç ile dört saat arası, hafta sonu ise dört saatten fazla televizyon izlemektedir (Tüzün 2002; Bersley \& Eenwyk 2001). Bu yoğunlukta televizyon izleme işlemine maruz kalan çocuklar 18 yaşına gelmeden önce televizyonda en az 30 bin adam öldürme olayına şahit olmaktadır. Devamlı bir şekilde televizyonlarda bıçak, silah, zehir gibi suç araçları gören ve problemlerin şiddet yolu ile çözüldüğünü fark eden çocuklar, zaman içinde bu durumu kanıksayarak farkında olmasa bile yavaş yavaş şiddet eğilimli insanlara dönüşmektedirler (Yavuzer 2007). Ayrıca televizyon ekranlarından izlenebilen sigara, alkol, uyuşturucu gibi bazı maddeler çocuklar tarafindan normal görülmeye başlanmaktadır.

Yapılan araştırmalar, bilgisayar teknolojilerinin ve internetin çocuklar üzerinde televizyondan daha fazla etkisinin olduğunu ve insanların bu kitle iletişim araçları ile televizyonda geçirdikleri vakitten daha fazla zaman geçirdikleri göstermektedir (Chisholm 2006). Berson ve Berson (2003) yaptıkları araştırmada 12-18 yaşları arasındaki genç kızların \%75'inin zamanlarının büyük kısmını sohbet odalarında ve e-posta ile mesajlaşarak geçirdiklerini ortaya çıkarmış- 
tır. Bunların yanında internet aracılığı ile şiddet içerikli oyunlar oynamanın şiddet algısını çocuklara yerleştirdiği bilinmektedir. Ayrıca evlerinde bilgisayar ve internet olmayan çocuklar s1k s1k internet kafelere giderek oradaki olumsuz atmosferi yaşamakta ve maddi olarak ciddi miktarda paralar vererek bu iletişim araçlarını kullanmaya çalışmaktadır (Tarı-Cömert \& Kayıran 2010). Beentjes ve diğerleri (2001), 6-16 yaş aralığındaki çocukların en fazla kullandıkları medya aracının sanal ortamda oynanan oyunlar olduğunu ifade etmektedir. Bununla birlikte bilgisayar oyunlarının, yazılımların devamlı bir şekilde geliştirilmesi ile daha gerçekçi bir hale geldiği ve çocukların bu durumdan her geçen gün daha fazla etkilediği görülmektedir (Evcin 2010).

$\mathrm{Bu}$ noktada öğretmenlerin sınıflarındaki öğrencilerinin kitle iletişim araçlarını kullanma durumlarını iyi bir şekilde analiz edip elde ettiği sonuçlar doğrultusunda kurallar belirlemesi (Shechtman \& Leichtentritt 2004) ve istendik davranışlara ulaşabilmek amacı ile sınıf yönetimini etkin bir şekilde sağlayarak eğitim-öğretimi devam ettirmesi gerekmektedir (Lewis \& Burman 2006; Çalışkan-Ülkü \& Demir 2013).

$\mathrm{Bu}$ kapsamda yapılan araştırmanın amacı, ilkokul öğrencilerinin sınıf içi davranışlarında belirleyici faktörlerden bir tanesi olan kitle iletişim araçlarının öğrencilerin sınıf içi davranışlarına etkisinin ne olduğu belirlemektir.

\section{Yöntem}

Çalışma var olan durumu olduğu sekliyle ortaya koymayı amaçladığı için betimsel tarama modeli kullanılmıştır (Karasar 2012).

\section{Araştırma Grubu}

Çalışma grubunu, 2014-2015 öğretim yılında Bursa İli Yıldırım, Nilüfer ve Osmangazi İlçeleri'nde yer alan Milli Eğitim Bakanlı̆̆ı'na bağlı ilkokullarda görev yapan 84'ü kadın ve 66'sı erkek olmak üzere 150 sınıf öğretmeni oluşturmaktadır.

\section{Veri Toplama Araçları}

Çalışmada, Çalışkan-Ülkü (2011) tarafinda geliştirilen "Kitle İletişim Araçlarının İlköğretim 15. Sinıf Öğrencilerinin Sinıf İçi Davranışlarına Etkisi Üzerine Öğretmen Görüşleri Ölçeği”" kullanılmıştır. Bu araştırmada ölçeğin güvenirliğini belirleyen Cronbach Alfa katsayısı 0.93 olarak bulunduğu ifade edilmektedir. Kitle İletişim Araçlarından Kaynaklanan Öğrenci Davranışları Ölçeği’nden elde edilebilecek azami puan "132", asgari puan ise, "44" dür.

\section{Verilerin Değerlendirilmesi}

Elde edilen verilerin istatistiksel analizinde SPSS 20.0 paket programı kullanılmıştır. Verilerin normallik dağılımını kontrol etmek için Kolmogorow-Smirnow testinden faydalanılmıştır. Veriler normal dağılım gösterdiği için parametrik testlerden olan Indepent Samples t testi ve Tek Yönlü Varyans Analizi (ANOVA) testleri kullanılmıştır.

Araştırmadan elde edilen toplam puanların (44-132 puan aralığı) yorumlanmasında kullanılan aralıklar da şu şekildedir:

44-73 puan: Olumsuz düzeyde kitle iletişim aracı etkisi

74-102 puan: Orta düzey (olumlu-olumsuz) kitle iletişim aracı etkisi

103-132 puan: Olumlu düzeyde kitle iletişim aracı etkisi

\section{Bulgular}

Yapılan istatistiki analiz sonucunda Kolmogorow-Smirnow değeri 0,20 olarak tespit edilmiştir. 
Elde edilen bu değer ve normallik durumunun görsel olarak gösterildiği histogram grafiği verilerin normal dağıldığı bilgisini vermektedir. Buna göre yapılacak işlemlerde parametrik testler kullanılmıştır.

\section{Kitle İletişim Araçlarının Sınıf İçi Öğrenci Davranışlarına Etkisine İlişkin Bulguların Cinsiyet Açısından Değerlendirilmesi}

Tablo 1. Sınıf Öğretmenlerinin Kitle İletişim Araçlarının Sınıf İçi Öğrenci Davranışlarına Etkisine İlişkin Görüşlerinin Cinsiyete Göre Farklılığı

\begin{tabular}{lllllll}
\hline Cinsiyet & $\mathbf{N}$ & $\begin{array}{l}\text { Aritmetik } \\
\text { Ortalama }\end{array}$ & Ss & Sd & $\mathbf{t}$ & $\mathbf{p}$ \\
& & 90,65 & 10,49 & 148 & 0,005 & 0,62 \\
\hline Erkek & 66 & 90,64 & 12,44 & & & \\
Kadin & 84 & & & & &
\end{tabular}

Tablo 1 incelendiğinde sınıf öğretmenlerinin kitle iletişim araçlarının sınıf içi öğrenci davranışlarına etkisine ilişkin görüşlerinin, cinsiyete göre anlamlı bir farklılık göstermediği görülmekte$\operatorname{dir}\{\mathrm{t}(148)=0,005 \mathrm{p}>.05\}$. Ortalamalar incelendiğinde ise kadın öğretmenlerin ortalama puanı $(90,64)$ erkek öğretmenlerin ortalama puanı ise $(90,65)$ olduğu ve bu puanlara göre sinıf öğretmenlerinin kitle iletişim araçlarının sınıf içi öğrenci davranışlarına etkisine ilişkin görüşlerinin birbirine yakın düzeyde olduğu görülmektedir. $\mathrm{Bu}$ verilere göre, cinsiyet açısından sınıf öğretmenlerinin sınıflarındaki öğrenci davranışlarının kitle iletişim araçlarından etkilenme derecesinin orta düzeyde olduğu belirlenmiştir.

\section{Kitle İletişim Araçlarının Sınıf İçi Öğrenci Davranışlarına Etkisine İlişskin Bulguların} Kıdem Durumuna Göre Değerlendirilmesi

Tablo 2. Sınıf Öğretmenlerinin Kitle İletişim Araçlarının Sınıf İçi Öğrenci Davranışlarına Etkisine İlişkin Görüşlerinin Kıdem Durumuna Göre Farklılığı

\begin{tabular}{llllllll}
\hline $\begin{array}{l}\text { Mesleki } \\
\text { Kidem }\end{array}$ & N & M & Ss & Sd & F & P & $\begin{array}{l}\text { Tukey } \\
\text { (Fark) }\end{array}$ \\
\hline 1-10 Y1l & 73 & 90,64 & 12,71 & 2 & 0,365 & 0,61 & \\
$11-20$ Y11 & 54 & 91,39 & 10,39 & & & & \\
$21-30$ Y11 & 23 & 88,91 & 10,77 & & & & \\
Toplam & 230 & 90,65 & 11,58 & & & & \\
\hline
\end{tabular}

*p $>0,05$

Tablo 2 incelendiğinde sınıf öğretmenlerinin kitle iletişim araçlarının sınıf içi öğrenci davranışlarına etkisine ilişkin görüşlerinin, öğretmenlerin mesleki kıdemlerine göre anlamlı bir farklılık göstermediği görülmektedir. $\{\mathrm{F}(2-148)=0,365 ; \mathrm{p}>05\}$.

Mesleki k1dem durumuna göre ortalamalar incelendiğinde ise 1-10 y1l arası öğretmenlerin toplam puanlarının aritmetik ortalaması 90,64; 11-20 yıl arası ögretmenlerin toplam puanlarının aritmetik ortalaması 91,39; 21-30 y1l arası ögretmenlerin toplam puanlarının aritmetik ortalaması 88,91 olarak saptanmıştır. Bu puanlara göre sınıf öğretmenlerinin kitle iletişim araçlarının sınıf içi öğrenci davranışlarına etkisine ilişkin görüşlerinin birbirine yakın düzeyde olduğu görülmektedir. Bu verilere göre, mesleki kıdem açısından sınıf öğretmenlerinin sınıflarındaki öğrenci davranışlarının kitle iletişim araçlarından etkilenme derecesinin orta düzeyde olduğu belirlenmiştir. 
Kitle İletişim Araçlarının Sınıf İçi Öğrenci Davranışlarına Etkisine İlişkin Bulguların Görev Yapılan Yere Göre Değerlendirilmesi

Tablo 3. Sınıf Öğretmenlerinin Kitle İletişim Araçlarının Sınıf İçi Öğrenci Davranışlarına Etkisine İlişkin Görüşlerinin Görev Yapılan Yere Göre Farklılığı

\begin{tabular}{lllllll}
\hline Görev Yeri & $\mathbf{N}$ & $\begin{array}{l}\text { Aritmetik } \\
\text { Ortalama }\end{array}$ & Ss & Sd & t & p \\
\hline İl & 115 & 90,70 & 11,24 & 148 & 0,94 & 0,92 \\
İlçe & 35 & 90,49 & 12,82 & & &
\end{tabular}

Tablo 3 incelendiğinde sınıf öğretmenlerinin kitle iletişim araçlarının sınıf içi öğrenci davranışlarına etkisine ilişkin görüşlerinin, görev yaptıkları yere göre anlamlı bir farklılık göstermediği görülmektedir $\{\mathrm{t}(148)=0,94 \mathrm{p}>.05\}$. Görev yapılan yere göre ortalamalar incelendiğinde ise ilde görev yapan öğretmenlerin toplam puanlarının aritmetik ortalaması 90,70; ilçede görev yapan öğretmenlerin toplam puanlarının aritmetik ortalaması 90,49 olarak saptanmıştır. Bu bulgulara göre sınıf öğretmenlerinin kitle iletişim araçlarının sınıf içi öğrenci davranışlarına etkisine ilişkin görüşlerinin birbirine yakın düzeyde olduğu görülmektedir. Bu verilere göre, görev yapılan yere göre sınıf öğretmenlerinin sınıflarındaki öğrenci davranışlarının kitle iletişim araçlarından etkilenme derecesinin orta düzeyde olduğu belirlenmiştir.

Kitle İletişim Araçlarının Sınıf İçi Öğrenci Davranışlarına Etkisine İlişkin Bulguların Öğrencilerin İkamet Ettiği Yere Göre Değerlendirilmesi

Tablo 4. Sınıf Öğretmenlerinin Kitle İletişim Araçlarının Sınıf İçi Öğrenci Davranışlarına Etkisine İlişkin Görüşlerinin Öğrencilerin İkamet Ettiği Yer Durumuna Göre Farklılığ1

\begin{tabular}{llllllll}
\hline $\begin{array}{l}\text { Öğrenci } \\
\text { İkamet Yeri }\end{array}$ & N & M & Ss & Sd & F & P & $\begin{array}{l}\text { Tukey } \\
\text { (Fark) }\end{array}$ \\
\hline İl & 108 & 90,52 & 11,32 & 2 & 0,041 & 0,96 & \\
İlçe & 40 & 90,90 & 12,61 & & & & \\
Köy & 2 & 92,50 & 9,19 & & & \\
Toplam & 150 & 90,65 & 11,58 & & & & \\
\hline
\end{tabular}

${ }^{*} \mathrm{p}>0,05$

Tablo 4 incelendiğinde sınıf öğretmenlerinin kitle iletişim araçlarının sınıf içi öğrenci davranışlarına etkisine ilişkin görüşlerinin, öğrencilerin ikamet ettiği yere göre anlamlı bir farklılık göstermediği görülmektedir $\{\mathrm{F}(2-148)=0,041 ; \mathrm{p}>05\}$.

Öğrencilerin ikamet ettiği yere göre ortalamalar incelendiğinde ilde ikamet eden öğrencilere sahip öğretmenlerin toplam puanlarının aritmetik ortalaması 90,52; ilçede ikamet eden öğrencilere sahip öğretmenlerin toplam puanlarının aritmetik ortalaması 90,90; köyde ikamet eden öğrencilere sahip öğretmenlerin toplam puanlarının aritmetik ortalaması 92,50 olarak saptanmıştır. $\mathrm{Bu}$ puanlara göre sınıf öğretmenlerinin kitle iletişim araçlarının sınıf içi öğrenci davranışlarına etkisine ilişkin görüşlerinin birbirine yakın düzeyde olduğu görülmektedir. Bu verilere göre, öğrencilerin ikamet ettiği yere göre sınıf öğretmenlerinin sınıflarındaki öğrenci davranışlarının kitle iletişim araçlarından etkilenme derecesinin orta düzeyde olduğu belirlenmiştir. 
Kitle İletişim Araçlarının Sınıf İçi Öğrenci Davranışlarına Etkisine İlişkin Bulguların Öğrencilerin Ekonomik Düzeyi Durumuna Göre Değerlendirilmesi

Tablo 5: Sınıf Öğretmenlerinin Kitle İletişim Araçlarının Sınıf İçi Öğrenci Davranışlarına Etkisine İlişkin Görüşlerinin Öğrencilerin Ekonomik Düzeyi Durumuna Göre Farklılığı

\begin{tabular}{|c|c|c|c|c|c|c|c|}
\hline $\begin{array}{l}\text { Ekonomik } \\
\text { Düzey }\end{array}$ & $\mathbf{N}$ & $\mathbf{M}$ & Ss & Sd & $\mathbf{F}$ & $\mathbf{P}$ & $\begin{array}{l}\text { Tukey } \\
\text { (Fark) } \\
\end{array}$ \\
\hline Yüksek & 28 & 93,36 & 11,3 & 2 & 1,369 & 0,224 & \\
\hline Orta & 50 & 91,18 & 11,31 & & & & \\
\hline Düşük & 72 & 89,22 & 11,79 & & & & \\
\hline Toplam & 150 & 90,65 & 11,58 & & & & \\
\hline
\end{tabular}

Tablo 5 incelendiğinde sınıf öğretmenlerinin kitle iletişim araçlarının sınıf içi öğrenci davranışlarına etkisine ilişkin görüşlerinin, öğrencilerin ekonomik düzeyine göre anlamlı bir farkl11ık göstermediği görülmektedir $\{\mathrm{F}(2-148)=1,369 ; \mathrm{p}>05\}$.

Öğrencilerin ekonomik düzeyine göre ortalamalar incelendiğinde öğrencileri yüksek ekonomik düzeyde olan öğretmenlerin toplam puanlarının aritmetik ortalamas 193,36, öğrencileri orta ekonomik düzeyde olan öğretmenlerin toplam puanlarının aritmetik ortalaması 91,18; öğrencileri düşük ekonomik düzeyde olan öğretmenlerin toplam puanlarının aritmetik ortalaması 89,22 olarak saptanmıştır. Bu puanlara göre sınıf öğretmenlerinin kitle iletişim araçlarının sınıf içi öğrenci davranışlarına etkisine ilişkin görüşlerinin birbirine yakın düzeyde olduğu görülmektedir. Elde edilen veriler ışığında, öğrencilerin ekonomik düzeyine göre sınıf öğretmenlerinin sınıflarındaki öğrenci davranışlarının kitle iletişim araçlarından etkilenme derecesinin orta düzeyde olduğu belirlenmiştir.

\section{Tartışma Sonuç ve Öneriler}

Yapılan araştırmada, sınıf öğretmenlerinin kitle iletişim araçlarının sınıf içi öğrenci davranışlarına etkisine ilişkin görüşlerinde cinsiyet, mesleki kıdem, görev yapılan yer, öğrencilerin ikamet ettikleri yer ve ekonomik düzeylerinin anlamlı bir değişken olmadığı sonucuna ulaşılmıştır.

Bununla beraber bazı değişkenlerin, kitle iletişim araçlarının öğrenci davranışlarını anlamlı olmasa bile incelemeye değer miktarda farklılaştırdığı görülmektedir. Kitle iletişim araçlarının öğrenci davranışlarını etkilediği görüşü cinsiyet ve görev yapılan yere göre neredeyse hiç değişmemektedir. Yani elde edilen değerler birbirine rakamsal olarak aynı diyebileceğimiz derecede yakındır. Çalışkan-Ülkü ve Demir'de (2013) kadın ve erkek öğretmenlerin kitle iletişim araçlarının öğrenci davranışlarına etkisi yönünde farklılık bulunmadığını tespit etmiştir. Kitle iletişim araçları iletişimi etkileyen önemli öğelerden biri olarak görüldüğü için iletişim becerileri ile cinsiyet arasındaki ilişkinin incelendiği çalışmaların sonuçlarının da burada değerlendirilmesi doğru olacaktır. $\mathrm{Bu}$ açıdan benzer olarak iletişim becerileri ile cinsiyet değişkeni arasında anlamlı farklılık tespit edilmeyen başka çalışmalar da bulunmaktadır (Pehlivan 2005; Dilekmen, Başçı \& Bektaş 2008; Ergün 2009; Çiftçi \& Taşkaya 2010; Çevik 2011). Alan yazında cinsiyet değişkeni açısından, kitle iletişim araçları kullanmanın bireylerin davranış durumlarında bir farklılaşma yaratmadığı sonuçlarının ağırlıklı olmasına rağmen bunun tersi sonuçlar da mevcuttur. Örneğin Evcin (2010) yaptığı çalışmada iki saat süre ile şiddet içerikli bilgisayar oyunu oynayan kız çocuklarının, saldırganlık, taşkınlık ve olumsuz davranışlarının erkeklerden anlamlı düzeyde yüksek olduğu sonucuna ulaşmıştır. Nacar (2010) da benzer şekilde cinsiyet değişkenine göre iletişim ve kişilerarası problem çözme becerilerinin farklılaştığı sonucunu elde ettiği 
görülmektedir.

Araştırmada kitle iletişim araçlarının, öğrencinin davranışlarını etkileme düzeylerinin öğretmenin görev yaptıkları yere göre değişmediği tespit edilmiştir. Ocak ve Erşen (2015) ve Acar'ın (2009) da yaptığı çalışmalarda benzer sonuçlar elde edildiği görülmektedir. Bununla birlikte Çalışkan-Ülkü ve Demir (2013) öğretmenlerin görev yerlerinin, kitle iletişim araçlarının öğrenci davranışlarını değiştirmesi noktasında farklılık gösterdiğini belirtmiştir. Araştırmacılar, köyde görev yapan öğretmenlerin, öğrencilerinin internet ve bilgisayar gibi teknolojik araçlara daha zor ulaştıklarını ve kitle iletişim araçlarının onları daha az olumsuz etkilediğini dile getirmişlerdir.

Bununla birlikte mesleki kıdem durumlarına göre öğretmen görüşlerinde anlamlı olmasa bile farklılıklar bulunmaktadır. Mesleğinde 20 y1lı geçen öğretmenler, diğer öğretmenlere göre (1-10 yıl, 11-20 yıl) kitle iletişim araçlarının öğrenci davranışlarını daha olumsuz yönde etkilediğini belirtmişlerdir. Çalışkan-Ülkü ve Demir (2013) ile Nacar (2010) da çalışmalarında benzer sonuçlara ulaşmıştır. Çalışkan-Ülkü ve Demir'e (2013) göre, öğretmenlerin mesleki kıdemlerine göre öğrencilerin kitle iletişim araçlarından etkilenerek davranış geliştirme düzeyleri arasında anlamlı bir farklılık bulunmaktadır. Buna göre 1-10 yıl arasındaki mesleki kıdeme sahip öğretmenlerin öğrencileri sosyal medyanın olumsuz etkilerine daha az maruz kalmaktadır. Kıdemi daha düşük olan öğretmenlerin teknolojiyi daha rahat kullanarak öğrencilerini de teknolojinin olumsuz etkilerinden uzak tuttuğu görülmektedir.

Yapılan çalışmada öğrencilerinin ikamet ettiği yerlere göre öğretmenlerin görüşleri de anlamlı olmasa bile farklılık göstermektedir. Öğrencileri il ve ilçelerde yaşayan öğretmenlerin, kitle iletişim araçlarının öğrenci davranışlarını, öğrencileri köyde yaşayan öğretmenlere göre daha olumsuz etkilediğini belirtmişlerdir. Bu sonuç köyde yaşayan öğrencilerin kitle iletişim araçlarının olumsuz etkilerine daha az maruz olduğu görüşünü desteklemektedir.

Puanlar arasında en çok farklılık gözlenen değişken ise öğrencilerin sosyo-ekonomik düzeylerine göre öğretmen görüşleridir. Öğrencilerin sosyo-ekonomik düzeyleri düştükçe öğretmenler kitle iletişim araçlarının öğrenci davranışlarını daha olumsuz etkilediği üzerinde durmuştur. Daha açık bir şekilde ifade etmek gerekirse öğretmenler, yüksek sosyo-ekonomik düzeydeki öğrencilerin davranışlarının, orta sosyo-ekonomik düzeydeki öğrenci davranışlarına göre kitle iletişim araçlarından daha olumlu etkilendiğini dile getirmektedir. Benzer şekilde orta sosyoekonomik düzeydeki öğrencilerin davranışlarının, düşük sosyo-ekonomik düzeydeki öğrenci davranışlarına göre kitle iletişim araçlarından daha olumlu etkilendiği görülmektedir. ÇalışkanÜlkü ve Demir (2013) ise öğrencilerin sosyo-ekonomik düzeylerinin, onların kitle iletişim araçlarından etkilenme düzeyleri ile arasında anlamlı bir fark olduğunu dile getirmiştir. Buna göre yüksek sosyo-ekonomik düzeydeki öğrenciler kitle iletişim araçlarının olumsuz etkilerini orta ve düşük sosyo-ekonomik düzeydeki öğrencilere göre daha fazla hissetmektedir. Ergün (2009) ve Nacar (2010) da yaptığı araştırmada sosyo-ekonomik düzeyin kitle iletişim araçlarının öğrenci davranışlarını etkileme noktasında önemli bir değişken olduğu sonucuna varmaktadır.

Sonuç olarak kitle iletişim araçlarının öğrenci davranışlarını bazı durumlarda daha olumsuz etkilediği görülmektedir. Şehirde yaşayan, düşük sosyo-ekonomik düzeye sahip öğrencilerin ve mesleki kıdemi 20 yılın üzerinde olan öğretmenlerin öğrencilerinin kitle iletişim araçlarının olumsuzluklarından daha fazla etkilendiği ortaya çıkmıştır.

Yapılan araştırmanın sonuçlarına göre tavsiye edilen öneriler aşağıda sunulmuştur.

- Öğretmenlerin, öğrencilerin kitle iletişim araçlarını kullanmalarının bir ihtiyaç olduğunu bilmesi ve bu doğrultuda onları bilinçlendirmesi gerekmektedir. 
- Öğretmenler, internetin ruhsal ve psikolojik sağlığa olumsuz etkilerini azaltmak için öğrencilere internet kullanımı konusunda eğitim vermelidir.

- Araştırmacılar, internetin ve kitle iletişim araçlarının eğitim-öğretim sürecine en iyi şekilde nasıl adapte edileceğine yönelik deneysel araştırmalar yapmalıdır.

- Aileler ve öğretmenler, öğrencilerin televizyon izleme ve internet kullanma saatlerini kısıtlamalı ve eğitici programları seçerek öğrencilerin bu programlar ile etkileşimli olmasını sağlamalıdır.

- Çocukların küçük yaşlardan itibaren kitle iletişim araçları ile birlikte olmasından dolayı yapılan araştırmanın okul öncesi dönemden itibaren eğitim öğretimin farklı kademelerinde de uygulanmasi gerekmektedir.

- Ailelere kitle iletişim araçları, internet ve akıllı cep telefonlarının kullanımı konusunda eğitimler verilmeli ve bu araçların iletişim amaçlı kullanılmasının gerekliliği üzerine bilgilendirmeler yapılmalıdır.

\section{KAYNAKÇA}

Acar V. (2009). Öğretmen Adaylarının İletişim Becerileri. Yayımlanmamış Yüksek Lisans Tezi. Mehmet Akif Ersoy Üniversitesi, Sosyal Bilimler Enstitüsü, Eğitim Bilimleri Anabilim Dalı, Burdur 2009.

Ayers H. \& Gray F. (1998). Classroom Management: Apractical Approach for Primary and Secondary Teachers. London 1998.

Beentjes J. W., Koolstra C. M., Marseille N. \& Van der Voort T. H. (2001). "Children's Use of Different Media: For How Long and Why". Children and Their Changing Media Environment: A European Comparative Study (2001) 85-112.

Bensley L. \& Eenwyk J. V. (2001). "Video Games and Real-Life Aggression: Review of the Literature". Journal of Adolescent Health 29 (2001) 244-257.

Berson I. \& Berson M. (2003). "Digital Literacy for Effective Citizenship". SocialEducation 67/3 (2003) 164-167.

Chisholm J. F. (2006). "Cybers Pace Violence Against Girls and Adolescent Females". Annals New York Academy of Sciences 1087(2006) 74-89.

Cüceloğlu D. (2002). İletişim Donanımları. İstanbul 2002.

Çakmak M., Kayabaşı Y. \& Ercan L. (2008). “Öğretmen Adaylarının Sınıf Yönetimi Stratejilerine İlişkin Görüşleri”. Hacettepe Üniversitesi Eğitim Fakültesi Dergisi 35 (2008) 53-64.

Çalışkan-Ülkü E. \& Demir M. K. (2013). "Kitle İletişim Araçlarının Öğrencilerin Sınıf İçi Davranışlarına Etkisi”. The Journal of Academic Social Science Studies 6/1 (2013) 587-608.

Çalışkan-Ülkü E. (2011). Kitle İletişim Araçlarının Öğrencilerin Sinıf İçi Davranışlarına Etkisi Üzerine Öğretmen Görüşleri. Yayımlanmamış Yüksek Lisans Tezi. Çanakkale Onsekiz Mart Üniversitesi, Sosyal Bilimler Enstitüsü, Çanakkale 2011.

Çam S. (1997). İletişim Becerileri Eğitim programının Öğretmen Adaylarının Ego Durumuna ve Problem Çözme Becerisi Algılarına Etkisi. Yayımlanmamış Doktora Tezi. Ankara Üniversitesi, Sosyal Bilimler Enstitüsü, Ankara 1997.

Çetinkanat A. C. (1997). "Öğretmenlerin İletişim Becerileri”. 3.Ulusal Sinı Öğretmenliği Sempozyumu (23-24 Ekim). Çukurova Üniversitesi, Adana 1997.

Çevik D. B. (2011). Müzik Öğretmeni Adaylarının İletişim Becerileri. Gazi Üniversitesi Gazi Eğitim Fakültesi Dergisi 31/1 (2011) 1-13. 
Çiftçi S. \& Taşkaya S. M. (2010). "Sınıf Öğretmeni Adaylarının Öz Yeterlik ve İletişim Becerileri Arasındaki İlişki”. IX. Ulusal Sinıf Öğretmenliği Ĕ̌itimi Sempozyumu. Fırat Üniversitesi, Elazığ 2010.

Dilekmen M., Başcı Z. \& Bektaş F. (2008). "Eğitim Fakültesi Öğrencilerinin İletişim Becerileri”. Atatürk Üniversitesi Sosyal Bilimler Enstitüsü Dergisi 12/2 (2008) 223-231.

Ergün D. (2009). İlköğretim Öğrencilerinin Öğretmenleri ile Kurdukları İletişime İlişkin Var Olan ve Beklenilen Duruma Yönelik Görüşlerinin İncelenmesi. Yüksek Lisans Tezi. Yüzüncü Yıl Üniversitesi, Sosyal Bilimler Enstitüsü, Van 2009.

Evcin S. (2010). Bilgisayar Oyunlarının İlköğretim İkinci Kademe Öğrencilerinin Saldırganlı Eğilimine Etkisinin İncelenmesi. Yayımlanmamış Yüksek Lisans Tezi. Maltepe Üniversitesi, İstanbul 2010.

Gökçe O. (2006). İletişim Bilimi-İnsan İlişkilerinin Anatomisi. Ankara 2006.

Halawah I. (2005). "The Relationship between Effective Communication of High School Principal and School Climate". Education 126/2 (2005) 334-345.

Hirsch E. \& Silverstone R. (Eds.). (2003). Consuming Technologies: Media and Information in Domestic Spaces. Routledge 2003.

Karasar N. (2012). Bilimsel Araştırma Yöntemi: Kavramlar, Ilkeler, Teknikler. Ankara 2012.

Kio S. L. \& Negreiros J. (2013). "Facebook as an Informal Learning Space Channel: The São José, Macao, Cases". Learning and Teaching in Computing and Engineering (2013) 70-76.

Lewis R. \& Burman E. (2006). "Providing for Student Voice in Classroom Management: Teachers' Views". International Journal of Inclusive Education (2006) 1-17.

Little E. (2005). "Secondary School Teachers' Perceptions of Students' Problem Behaviours". Educational Psycholog 25/4 (2005) 369-377.

McQuail D. (2010). McQuail's Mass Communication Theory. LA 2010.

Nacar F. S. (2010). Sinlf Öğretmenlerinin İletişim ve Kişilerarası Problem Çözme Becerilerinin İncelenmesi. Yayımlanmamış Yüksek Lisans Tezi. Çukurova Üniversitesi, Sosyal Bilimler Enstitüsü, Adana 2010.

Ocak G. \& Erşen Z. B. (2015). "Öğretmen Adaylarının İletişim Becerileri Algılarının İncelenmesi”. Mehmet Akif Ersoy Üniversitesi Ë̆itim Fakültesi Dergisi 33 (2015) 1-19.

Pehlivan K. B. (2005). “Öğretmen Adaylarının İletişim Becerisi Algıları Üzerine Bir Çalışma”. İlköğretimOnline 4/2 (2005) 17-23.

Shechtman Z. \& Leichtentritt J. (2004). "Affective Teaching: A Method to Enhance Classroom Management". European Journal of Teacher Education 27/3 (2004) 323-333.

Smith C. J. \& Laslett R. (1996²). Effective Classroom Management: A Teacher Guide. London 1996.

Şencan A. C. (2010). İlköğretimde Öğretmen-Öğrenci İletişiminden Öğrencilerin Beklentileri. Yüksek Lisans Tezi. Yeditepe Üniversitesi, Sosyal Bilimler Enstitüsü, İstanbul 2010.

Tarı-Cömert I. \& Kayıran S. M. (2010). "Çocuk ve Ergenlerde İnternet Kullanımı”. Çocuk Dergisi 10/4 (2010) 166-170.

Tavşanlı Ö. F., Birgül K. \& Oksal A. (2016). "Ortaokul Öğrencilerinin Okul İklimine Yönelik Algılarını Yordayan Değişkenlerin İncelenmesi”. Electronic Turkish Studies 11/9 (2016).

Tüzün Ü. (2002). "Gelişen İletişim Araçlarının Çocuk ve Gençlerin Etkileşimi Üzerine Etkisi”. Düşünen Adam Dergisi 15/1 (2002) 46-50.

Üre Ö. (2003). Sinıf Yönetimi. Ankara 2003.

Yavuzer H. (2007). Ana-Baba ve Çocuk. İstanbul 2007. 